\title{
Pilot Application of 'Invasive Alien Species in Europe' Smartphone App in the Danube Region
}

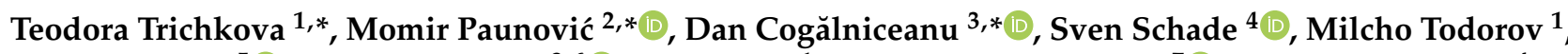 \\ Rumen Tomov ${ }^{5}{ }^{(}$, Florina Stănescu ${ }^{3,6}{ }^{(\mathbb{D}}$, Ivan Botev ${ }^{1}$, Celia López-Cañizares ${ }^{7}{ }^{\circ}$, Eugenio Gervasini ${ }^{4}$, \\ Zdravko Hubenov ${ }^{8}, \operatorname{Kostadin~Ignatov~}^{9}$, Marian Kenderov ${ }^{9}$, Nikola Marinković ${ }^{2}{ }^{\circledR}$, Irena Mitton ${ }^{10}$, \\ Cristina Preda ${ }^{3}{ }^{\complement}$, Fabiano Antonio Spinelli ${ }^{11}$, Konstantinos Tsiamis ${ }^{4}$ and Ana Cristina Cardoso ${ }^{4, *}$
}

Citation: Trichkova, T.; Paunović, M.; Cogălniceanu, D.; Schade, S.; Todorov, M.; Tomov, R.; Stănescu, F.; Botev, I. López-Cañizares, C.; Gervasini, E.; et al. Pilot Application of 'Invasive Alien Species in Europe' Smartphone App in the Danube Region. Water 2021, 13, 2952. https://doi.org/ $10.3390 / w 13212952$

\section{Academic Editors:}

Lyudmila Kamburska, Agnese Marchini and Hugh MacIsaac

Received: 24 September 2021 Accepted: 18 October 2021 Published: 20 October 2021

Publisher's Note: MDPI stays neutral with regard to jurisdictional claims in published maps and institutional affiliations.

Copyright: (c) 2021 by the authors. Licensee MDPI, Basel, Switzerland. This article is an open access article distributed under the terms and conditions of the Creative Commons Attribution (CC BY) license (https:/ / creativecommons.org/licenses/by/ $4.0 /)$.
1 Institute of Biodiversity and Ecosystem Research, Bulgarian Academy of Sciences (IBER-BAS), 1 Tsar Osvoboditel Blvd., 1000 Sofia, Bulgaria; todorovmilcho@gmail.com (M.T.); ibotev10@gmail.com (I.B.)

2 Institute for Biological Research 'Siniša Stanković', University of Belgrade, Bulevar Despota Stefana, 142, 11060 Belgrade, Serbia; nikola.marinkovic@ibiss.bg.ac.rs

3 Faculty of Natural and Agricultural Sciences, Ovidius University Constanța, 900470 Constanța, Romania; florina_stanescu@ymail.com (F.S.); cristina.preda@univ-ovidius.ro (C.P.)

4 European Commission, Joint Research Centre (JRC), 21027 Ispra, Italy; s.schade@ec.europa.eu (S.S.); Eugenio.GERVASINI@ec.europa.eu (E.G.); konstantinos.tsiamis@ec.europa.eu (K.T.)

5 Faculty of Agriculture, University of Forestry, 10 Kliment Ohridski Blvd., 1797 Sofia, Bulgaria; rtomov@yahoo.com

6 Black Sea Institute for Development and Security Studies, Ovidius University Constanța, 900470 Constanța, Romania

$7 \quad$ PIKSEL S.r.l., 20126 Milan, Italy; Celia.LOPEZ-CANIZARES@ext.ec.europa.eu

8 National Museum of Natural History, Bulgarian Academy of Sciences, 1 Tsar Osvoboditel Blvd., 1000 Sofia, Bulgaria; zhubenov@nmnhs.com

9 Biological Faculty, Sofia University 'St. Kliment Ohridski', 8 Dragan Tsankov Blvd., 1164 Sofia, Bulgaria; kostadin.ignatov@abv.bg (K.I.); marian_kenderov@abv.bg (M.K.)

10 MITGIS, 52210 Rovinj, Croatia; irena.mitton@ext.ec.europa.eu

11 GFT Technologies, 20139 Milan, Italy; fabiano-antonio.spinelli@ext.ec.europa.eu

* Correspondence: trichkova@gmail.com (T.T.); mpaunovi@ibiss.bg.ac.rs (M.P.); dcogalniceanu@univ-ovidius.ro (D.C.); ana-cristina.cardoso@ec.europa.eu (A.C.C.)

Abstract: The present pilot study tested and validated the use of the 'Invasive Alien Species in Europe' smartphone app (IASapp) in the Lower Danube Region. The study was conducted in three stages: (1) Testing the effectiveness of the app in Bulgaria, Romania and Serbia by organizing information and field testing campaigns; (2) Improving and extending the functionality of the app and developing a list of the invasive alien species (IAS) of concern to the Danube River Basin (DRB); and (3) Testing the updated app during the Joint Danube Survey 4 campaign. Overall, 13 campaigns were carried out, during which seven aquatic IAS of EU concern and nine IAS relevant to the DRB were recorded. Currently, the developed new functionality of IASapp allows the recording of 64 IAS of DRB concern. The updated IASapp has an important role in increasing public awareness on IAS issues, as well as in enlarging the participation and output of citizen science in the IAS early detection, monitoring and reporting in the DRB. Therefore, the constant communication with existing stakeholder groups and establishment of new citizen science groups is crucial for increasing the effectiveness of using the IASapp in the Danube Region and tackling the IAS issues.

Keywords: invasive alien species (IAS) of European Union concern; IAS of concern to the Danube River Basin; aquatic IAS; citizen science; mobile recording tool; early detection; monitoring; awareness raising

\section{Introduction}

Biological invasions are the consequence of an increasingly connected world, the rise in trade and size of human population [1]. Invasive alien species (IAS) have multiple 
environmental and socio-economic effects [2,3] and their management is increasingly costly [4]. A conservative estimate of the annual damages caused by IAS in the European Union (EU) is at least EUR 12 billion, but the cumulated costs probably reach EUR 20 billion per year [5,6]. Total costs of IAS in Europe summed to EUR 116.61 billion between 1960 and 2020, with the majority (60\%) being damage-related and impacting multiple sectors [7].

The Danube River, known as part of the Southern Invasion Corridor, is considered a major pathway for the spread of IAS in Europe [8-10]. Numerous surveys for documenting IAS along that corridor show that the rate of introduction and spread of IAS in the Danube Region, and their adverse impact on biodiversity has increased recently [9-25]. The results of the Joint Danube Survey 4 (JDS4) (2019), a field survey organized and coordinated by the International Commission for the Protection of the Danube River (ICPDR) every six years since 2001, have reconfirmed that the Danube River, its main tributaries and adjacent wetlands are under considerable impact from biological invasions [26]. The level of biocontamination (i.e., the number of alien species and their abundance in comparison to the total number of species and the community abundance) of the Danube River is estimated as moderate to high. Higher values are documented for the Upper (high to severe biocontamination) and Middle Danube (moderate to high biocontamination), in comparison to the Lower Danube (low biocontamination). In general, an increase in the number of the identified alien species is recorded compared to the previous JDSs, for example, the number of alien benthic macroinvertebrates has grown in number three times since JDS1 (2001) [26].

In response to the growing concern about the issue of IAS, significant European and regional instruments have recently been developed. The Regulation (EU) No. 1143/2014 of the European Parliament and of the Council of 22 October 2014 on the prevention and management of the introduction and spread of invasive alien species (IAS Regulation) entered into force on 1 January 2015 [27]. A list of the IAS of European Union (EU) concern was adopted and is being updated regularly by the European Commission (EC), together with the scientific community and the competent authorities of the Member States [28-30]. The ICPDR confirms that IAS have become an issue of major concern to the Danube River Basin (DRB) and IAS are included as such by the updated Danube River Basin Management Plans $(2015,2021)[31,32]$. The ICPDR has prepared a guidance document on the IAS relevant to the DRB, including tools for risk assessment and evaluation of impact [23]. Considering the importance of IAS in the context of EU Water Framework Directive [33], a specific IAS program was drawn up and implemented during JDS4 at national level [26,34-36].

In general, the information about IAS, including the data on occurrence of the species, has been collected by professionals, such as academics and governmental employees. However, citizen science represents an opportunity for engaging a wider participation in collecting such information with the help of volunteers [37,38]. Citizen science refers to the voluntary participation of people, scientists and non-scientists alike, in different phases of the scientific process, including data collection or analysis [39,40]. While adding value, participants acquire new knowledge, skills and gain more understanding of the scientific work [40]. Citizen science has become an increasingly popular and complementary approach to undertake science, including monitoring of biodiversity and the environment [41-44]. A wide range of projects building on the citizen involvement in surveillance, monitoring and management of a number of IAS is currently being implemented in Europe [45]. New technologies, such as smartphone application software (apps) and social media, are increasingly used to reach and engage a wider audience in learning about and recording IAS $[46,47]$.

The European Commission's Joint Research Centre (JRC) has developed the smartphone application 'Invasive Alien Species in Europe' (IASapp). Its aim is to enable the general public and professionals to receive and share information about the IAS of EU concern in Europe [48] and to complement the collection of data in the frame of the European Alien Species Information Network (EASIN), thus contributing to the implementation 
of IAS Regulation $[49,50]$. The IASapp has been promoted in certain regions of Europe, where public reporting on IAS requires support, such as the Iberian Peninsula, Sava River Basin and Malta. Additionally, efforts are being made to create a community of interest on alien species and IAS by raising public awareness and increasing collaboration under different initiatives, e.g., Alien CSI Cost Action CA17122 [51] and Massive Open Online Course (MOOC) 'Have you seen an alien?' [52], to stimulate citizen engagement in IAS monitoring.

The aim of the present study was to test and validate the use of IASapp in the Lower Danube Region. The study was conducted in three stages with the following objectives:

(1) Testing the effectiveness of the app in Bulgaria, Romania and Serbia, by organizing information and field testing campaigns (2016-2017);

(2) Improving and extending the functionality of the app at a regional level, based on the received feedback and results;

(3) Testing the updated app for IAS monitoring (2019).

\section{Materials and Methods}

\subsection{Study Period}

The early tests on IASapp were made in the period 2016 (November)-2017 (May-June), while the tests on the updated app were carried out in 2019 (July-October), during the JDS4 campaign.

\subsection{Study Area and Selection of Testing Sites}

The study area covered the Lower Danube Region-Bulgaria, Romania and Serbia. The information campaigns and meetings with stakeholders were held in all three countries, while the reporting of species using the IASapp was mainly performed in Bulgaria.

In 2016-2017, the testing sites were selected based on the following criteria: (1) Geographic scale-DRB; (2) Known or potential distribution of the IAS of EU concern; (3) Type of habitats-freshwater habitats, including the Danube River, Danube tributaries and standing water bodies; for demonstration, artificial ponds in parks and zoos were also visited; (4) Accessibility of sites-the sites were preferably selected close to large cities and towns (Sofia, Vidin, Constanța, Belgrade, etc.), easily accessible by roads for the participants in the testing.

In 2019, the updated IASapp was tested during field surveys at the JDS4 sites, in the frame of the IAS programs in Bulgaria and Serbia [26,36].

\subsection{Target Species}

The target species were the freshwater animal IAS of EU concern [28,29] (fish, decapods and terrapins) during the first stage of the testing, and the freshwater IAS of EU concern (plants, decapods and fish) [28,29] and DRB concern (invertebrates and fish) (Table 1) during JDS4. In the present paper, the taxonomy of invertebrates follows $[53,54]$, and the taxonomy of fish is according to $[55,56]$.

\subsection{Selection of Stakeholders}

The stakeholders invited to participate in the information and field testing campaigns during the early tests were selected based on the following criteria: professional expertise, groups of interest, potential motivation to participate, level of training, logistics and coordination requirements. The stakeholders identified in the three countries were grouped in the following categories: scientists, students, national and regional authorities, nongovernmental organizations, private and public companies, fishermen and other citizens that showed interest in the topic.

\subsection{Organization of the Information and Field Testing Campaigns}

Each testing using the IASapp was carried out in two steps: an information campaign followed by a field testing. The campaigns were organized as standalone events or together 
with other public activities, such as project meetings, information events and students' field training. The information campaign included: (1) sending out information materials, using various channels, such as email, post, websites and social media, printed materials disseminated in public places, etc., prior or during the events; and (2) presenting and discussing with participants about the IAS, IAS Regulation and possibilities of applying IASapp. The field testing phase included: (1) examples of sampling methods, depending on the species' features and local conditions, and involving the participants in sampling; (2) taking pictures of the species observed and recording the species using the IASapp; and (3) discussing and collecting feedback from the participants. All field campaigns were performed with the scientific and technical support of the scientists involved in the testing.

The two information campaigns and testing using the updated IASapp in 2019 were organized during JDS4. Joint Danube Surveys (JDS) have been conducted every six years since 2001 and coordinated by the International Commission for the Protection of the Danube River (ICPDR), with the aims to produce comparable data on water quality, to harmonize water monitoring practices and procedures at regional level, in accordance with the EU Water Framework Directive [33].

Standard sampling methods were used for collecting the species for registration. Thus, benthic macroinvertebrates were collected by hand, by dredging, or with the help of a dip net and sieves; fish were caught using beach seines, a dip net and gill nets, while terrapins were caught using nets or by hand. During JDS4, the samples were collected and processed according to the standard operational procedure for the IAS monitoring [23,34,35], and methods developed and tested in the frames of the projects ESENIAS-TOOLS [57] and IBBIS [58].

The feedback from participants was collected through a questionnaire containing three groups of questions regarding:

(1) Information about the participant-occupation and area of expertise;

(2) Information about previous knowledge on IAS and IAS Regulation; and

(3) Comments on the use of the IASapp, such as content, applicability, any technical or other issues encountered, and suggestions for improvement.

The completion of the questionnaire by the participants was optional and the data were used in the analyses only after receiving the participants' agreement.

\subsection{Development of a List of the IAS of Concern to the Danube River Basin}

Following the feedback provided by the first round of tests, and based on the Guidance document on IAS in the DRB [23], a list of the IAS of concern to the DRB was developed under the coordination of the ICPDR. The list contains 64 species, of which 43 aquatic invertebrates and 21 fish (Table 1). According to their origin, 25 of the listed species are alien to Europe (12 from Asia, 12 from North America, and one from New Zealand), while nine species are native to Europe (outside the Ponto-Caspian region), and 30 species are Ponto-Caspian (Table 1).

Table 1. List of the invasive alien species (aquatic invertebrates and fish) of concern to the Danube River Basin. *-The species is currently listed as IAS of EU concern [30].

\begin{tabular}{ccccc}
\hline No. & Phylum (Lower Taxon) & Scientific Name & Common Name & Native Range \\
\hline 1. & Cnidaria & $\begin{array}{c}\text { Invertebrates } \\
\text { Cordylophora caspia (Pallas, } \\
1771)\end{array}$ & Freshwater hydroid & Ponto-Caspian region \\
\hline 2. & Cnidaria & $\begin{array}{c}\text { Craspedacusta sowerbii } \\
\text { Lankester, 1880 }\end{array}$ & Freshwater jellyfish & Asia \\
\hline 3. & Platyhelminthes & $\begin{array}{c}\text { Dugesia tigrina (Girard, } \\
\text { 1850)/Girardia tigrina } \\
\text { (Girard, 1850) }\end{array}$ & Planarian & North America \\
\hline
\end{tabular}


Table 1. Cont.

\begin{tabular}{|c|c|c|c|c|}
\hline No. & Phylum (Lower Taxon) & Scientific Name & Common Name & Native Range \\
\hline 4. & Platyhelminthes & $\begin{array}{c}\text { Dendrocoelum } \\
\text { romanodanubiale (Codreanu, } \\
\text { 1949) }\end{array}$ & & Ponto-Caspian region \\
\hline 5. & Annelida (Polychaeta) & $\begin{array}{c}\text { Hypania invalida (Grube, } \\
\text { 1860) }\end{array}$ & & Ponto-Caspian region \\
\hline 6. & Annelida (Polychaeta) & $\begin{array}{c}\text { Manayunkia caspica } \\
\text { Annenkova, } 1928\end{array}$ & & Ponto-Caspian region \\
\hline 7. & Annelida (Oligochaeta) & $\begin{array}{l}\text { Branchiura sowerbyi } \\
\text { Beddard, } 1892\end{array}$ & & Asia \\
\hline 8. & Annelida (Oligochaeta) & $\begin{array}{c}\text { Potamothrix moldaviensis } \\
\text { Vejdovský and Mrázek, } \\
1903\end{array}$ & & Ponto-Caspian region \\
\hline 9. & Annelida (Hirudinea) & $\begin{array}{c}\text { Barbronia weberi (Blanchard, } \\
\text { 1897) }\end{array}$ & & Asia \\
\hline 10. & Annelida (Hirudinea) & $\begin{array}{l}\text { Caspiobdella fadejewi } \\
\text { Epshtein, } 1961\end{array}$ & & Ponto-Caspian region \\
\hline 11. & Annelida (Hirudinea) & Piscicola haranti Jarry, 1960 & & Europe (France) \\
\hline 12. & Arthropoda (Arachnida) & $\begin{array}{c}\text { Caspihalacarus hyrcanus } \\
\text { Viets, 1928/Halacarellus } \\
\text { hyrcanus (Viets, 1928) }\end{array}$ & & Ponto-Caspian region \\
\hline 13. & Arthropoda (Mysida) & $\begin{array}{c}\text { Katamysis warpachowskyi G. } \\
\text { O. Sars, } 1893\end{array}$ & & Ponto-Caspian region \\
\hline 14. & Arthropoda (Mysida) & $\begin{array}{l}\text { Limnomysis benedeni } \\
\text { Czerniavsky, } 1882\end{array}$ & Caspian slender shrimp & Ponto-Caspian region \\
\hline 15. & Arthropoda (Mysida) & $\begin{array}{l}\text { Paramysis lacustris } \\
\text { (Czerniavsky, 1882) }\end{array}$ & Opossum shrimp & Ponto-Caspian region \\
\hline 16. & $\begin{array}{l}\text { Arthropoda } \\
\text { (Amphipoda) }\end{array}$ & $\begin{array}{c}\text { Chaetogammarus } \\
\text { (Echinogammarus) ischnus } \\
\text { (Stebbing, 1899) }\end{array}$ & & Ponto-Caspian region \\
\hline 17. & $\begin{array}{l}\text { Arthropoda } \\
\text { (Amphipoda) }\end{array}$ & $\begin{array}{c}\text { Chaetogammarus trichiatus } \\
\text { Martynov, } \\
\text { 1932/Echinogammarus } \\
\text { trichiatus (Martynov, 1932) }\end{array}$ & & Ponto-Caspian region \\
\hline 18. & $\begin{array}{l}\text { Arthropoda } \\
\text { (Amphipoda) }\end{array}$ & $\begin{array}{l}\text { Chelicorophium curvispinum } \\
\text { (G. O. Sars, 1895) }\end{array}$ & & Ponto-Caspian region \\
\hline 19. & $\begin{array}{l}\text { Arthropoda } \\
\text { (Amphipoda) }\end{array}$ & $\begin{array}{c}\text { Chelicorophium robustum (G. } \\
\text { O.Sars, 1895) }\end{array}$ & & Ponto-Caspian region \\
\hline 20. & $\begin{array}{l}\text { Arthropoda } \\
\text { (Amphipoda) }\end{array}$ & $\begin{array}{c}\text { Chelicorophium sowinskyi } \\
\text { (Martynov, 1924) }\end{array}$ & & Ponto-Caspian region \\
\hline 21. & $\begin{array}{l}\text { Arthropoda } \\
\text { (Amphipoda) }\end{array}$ & $\begin{array}{c}\text { Crangonyx pseudogracilis } \\
\text { Bousfield, } 1958\end{array}$ & $\begin{array}{l}\text { Northern River } \\
\text { Crangonyctid }\end{array}$ & North America \\
\hline 22. & $\begin{array}{l}\text { Arthropoda } \\
\text { (Amphipoda) }\end{array}$ & $\begin{array}{c}\text { Dikerogammarus bispinosus } \\
\text { Martynov, } 1925\end{array}$ & & Ponto-Caspian region \\
\hline 23. & $\begin{array}{l}\text { Arthropoda } \\
\text { (Amphipoda) }\end{array}$ & $\begin{array}{c}\text { Dikerogammarus } \\
\text { haemobaphes (Eichwald, } \\
1841)\end{array}$ & Demon shrimp & Ponto-Caspian region \\
\hline 24. & $\begin{array}{l}\text { Arthropoda } \\
\text { (Amphipoda) }\end{array}$ & $\begin{array}{l}\text { Dikerogammarus villosus } \\
\quad \text { (Sowinsky, 1894) }\end{array}$ & Killer shrimp & Ponto-Caspian region \\
\hline 25. & $\begin{array}{l}\text { Arthropoda } \\
\text { (Amphipoda) }\end{array}$ & $\begin{array}{c}\text { Niphargus hrabei S. } \\
\text { Karaman, } 1932\end{array}$ & & Ponto-Caspian region \\
\hline
\end{tabular}


Table 1. Cont.

\begin{tabular}{|c|c|c|c|c|}
\hline No. & Phylum (Lower Taxon) & Scientific Name & Common Name & Native Range \\
\hline 26. & $\begin{array}{l}\text { Arthropoda } \\
\text { (Amphipoda) }\end{array}$ & $\begin{array}{c}\text { Obesogammarus obesus (G. } \\
\text { O. Sars, 1894) }\end{array}$ & & Ponto-Caspian region \\
\hline 27. & $\begin{array}{l}\text { Arthropoda } \\
\text { (Amphipoda) }\end{array}$ & $\begin{array}{c}\text { Orchestia cavimana Heller, } \\
\text { 1865/Cryptorchestia } \\
\text { cavimana (Heller, 1865) }\end{array}$ & & $\begin{array}{c}\text { Europe (Mediterranean } \\
\text { Sea) }\end{array}$ \\
\hline 28. & $\begin{array}{l}\text { Arthropoda } \\
\text { (Amphipoda) }\end{array}$ & $\begin{array}{c}\text { Pontogammarus robustoides } \\
\text { (Sars, 1894) }\end{array}$ & & Ponto-Caspian region \\
\hline 29. & $\begin{array}{l}\text { Arthropoda } \\
\text { (Amphipoda) }\end{array}$ & $\begin{array}{l}\text { Synurella ambulans (F. } \\
\text { Müller, 1846) }\end{array}$ & & Ponto-Caspian region \\
\hline 30. & Arthropoda (Isopoda) & Jaera sarsi Valkanov, 1936 & & Ponto-Caspian region \\
\hline 31. & Arthropoda (Isopoda) & $\begin{array}{l}\text { Proasellus coxalis (Dollfus, } \\
\text { 1892) }\end{array}$ & & $\begin{array}{c}\text { Europe (Mediterranean } \\
\text { Sea) }\end{array}$ \\
\hline 32. & Arthropoda (Insecta) & $\begin{array}{c}\text { Aedes (Stegomyia) albopictus } \\
\text { (Skuse, 1894) }\end{array}$ & Asian tiger mosquito & Asia \\
\hline 33. & Mollusca (Gastropoda) & $\begin{array}{c}\text { Borysthenia naticina (Menke, } \\
\text { 1845) }\end{array}$ & & Ponto-Caspian region \\
\hline 34. & Mollusca (Gastropoda) & $\begin{array}{c}\text { Melanoides tuberculata (O. F. } \\
\text { Müller, 1774) }\end{array}$ & Red-rimmed melania & Africa and Asia \\
\hline 35. & Mollusca (Gastropoda) & $\begin{array}{c}\text { Physella acuta (Draparnaud, } \\
\text { 1805) }\end{array}$ & $\begin{array}{l}\text { European physa, tadpole } \\
\text { snail }\end{array}$ & North America \\
\hline 36. & Mollusca (Gastropoda) & $\begin{array}{c}\text { Potamopyrgus antipodarum } \\
\text { (Gray, 1843) }\end{array}$ & New Zealand mud snail & New Zealand \\
\hline 37. & Mollusca (Bivalvia) & $\begin{array}{c}\text { Corbicula fluminalis (O. F. } \\
\text { Müller, 1774) }\end{array}$ & Asian clam & Asia \\
\hline 38. & Mollusca (Bivalvia) & $\begin{array}{c}\text { Corbicula fluminea (O. F. } \\
\text { Müller, 1774) }\end{array}$ & Asian clam & Asia \\
\hline 39. & Mollusca (Bivalvia) & $\begin{array}{l}\text { Dreissena polymorpha } \\
\quad(\text { Pallas, 1771) }\end{array}$ & Zebra mussel & Ponto-Caspian region \\
\hline 40. & Mollusca (Bivalvia) & $\begin{array}{c}\text { Dreissena rostriformis } \\
\text { bugensis Andrusov, } 1897\end{array}$ & Quagga mussel & Ponto-Caspian region \\
\hline 41. & Mollusca (Bivalvia) & $\begin{array}{l}\text { Sinanodonta woodiana (I. } \\
\text { Lea, 1834) }\end{array}$ & Chinese pond mussel & Asia \\
\hline 42. & Bryozoa & $\begin{array}{c}\text { Pectinatella magnifica (Leidy, } \\
\text { 1851) }\end{array}$ & Magnificent bryozoan & North America \\
\hline \multirow[t]{2}{*}{43.} & Entoprocta & $\begin{array}{l}\text { Urnatella gracilis Leidy, } \\
1851\end{array}$ & & North America \\
\hline & & Fish & & \\
\hline 44. & $\begin{array}{c}\text { Chordata } \\
\text { (Polyodontidae) }\end{array}$ & $\begin{array}{l}\text { Polyodon spathula } \\
\text { (Walbaum, 1792) }\end{array}$ & American paddlefish & North America \\
\hline 45. & Chordata (Cyprinidae) & $\begin{array}{c}\text { Alburnus albidus (Costa, } \\
\text { 1838) }\end{array}$ & Italian bleak & $\begin{array}{l}\text { Europe (Adriatic and } \\
\text { Tyrrhenian sea basins) }\end{array}$ \\
\hline 46. & Chordata (Cyprinidae) & $\begin{array}{c}\text { Carassius gibelio (Bloch, } \\
\text { 1782) }\end{array}$ & Prussian carp & Asia \\
\hline 47. & Chordata (Cyprinidae) & $\begin{array}{l}\text { Ctenopharyngodon idella } \\
\text { (Valenciennes, 1844) }\end{array}$ & Grass carp & Asia \\
\hline 48. & Chordata (Cyprinidae) & $\begin{array}{l}\text { Hypophthalmichthys molitrix } \\
\text { (Valenciennes, 1844) }\end{array}$ & Silver carp & Asia \\
\hline 49. & Chordata (Cyprinidae) & $\begin{array}{l}\text { Hypophthalmichthys nobilis } \\
\text { (Richardson, 1845) }\end{array}$ & Bighead carp & Asia \\
\hline
\end{tabular}


Table 1. Cont.

\begin{tabular}{|c|c|c|c|c|}
\hline No. & Phylum (Lower Taxon) & Scientific Name & Common Name & Native Range \\
\hline 50. & Chordata (Cyprinidae) & Leucos basak Heckel, 1843 & $\begin{array}{l}\text { Albanian/Dalmatian/ } \\
\text { Croatian roach }\end{array}$ & $\begin{array}{c}\text { Europe (Adriatic Sea } \\
\text { basin) }\end{array}$ \\
\hline 51. & Chordata (Cyprinidae) & $\begin{array}{l}\text { Pachychilon macedonicum } \\
\text { (Steindachner, 1892) }\end{array}$ & Mergur & $\begin{array}{c}\text { Europe (Aegean Sea } \\
\text { basin) }\end{array}$ \\
\hline 52. & Chordata (Cyprinidae) & $\begin{array}{l}\text { Scardinius graecus } \\
\text { Stephanidis, } 1937\end{array}$ & Greek rudd & $\begin{array}{c}\text { Europe (Aegean Sea } \\
\text { basin) }\end{array}$ \\
\hline 53. & Chordata (Ictaluridae) & $\begin{array}{c}\text { Ameiurus melas (Rafinesque, } \\
\text { 1820) }\end{array}$ & Black bullhead & North America \\
\hline 54. & Chordata (Ictaluridae) & $\begin{array}{l}\text { Ameiurus nebulosus } \\
\text { (Lesueur, 1819) }\end{array}$ & $\begin{array}{l}\text { Brown bullhead, horned } \\
\text { pout, mud cat }\end{array}$ & North America \\
\hline 55. & Chordata (Salmonidae) & $\begin{array}{c}\text { Coregonus peled (Gmelin, } \\
1789 \text { ) }\end{array}$ & Peled, northern whitefish & $\begin{array}{c}\text { Europe and Asia } \\
\text { (Arctic Ocean basin) }\end{array}$ \\
\hline 56. & Chordata (Salmonidae) & $\begin{array}{l}\text { Onchorhynchus mykiss } \\
\text { (Walbaum, 1792) }\end{array}$ & Rainbow trout & North America \\
\hline 57. & Chordata (Salmonidae) & $\begin{array}{c}\text { Salmo letnica (Karaman, } \\
1924)\end{array}$ & Ohrid trout & $\begin{array}{c}\text { Europe (Adriatic Sea } \\
\text { basin) }\end{array}$ \\
\hline 58. & Chordata (Salmonidae) & $\begin{array}{l}\text { Salvelinus fontinalis } \\
\text { (Mitchill, 1814) }\end{array}$ & Brook trout & North America \\
\hline 59. & Chordata (Gobiidae) & $\begin{array}{l}\text { Babka gymnotrachelus } \\
\text { (Kessler, 1857) }\end{array}$ & Racer goby & Ponto-Caspian region \\
\hline 60. & Chordata (Gobiidae) & $\begin{array}{c}\text { Neogobius fluviatilis (Pallas, } \\
1814 \text { ) }\end{array}$ & River goby, monkey goby & Ponto-Caspian region \\
\hline 61. & Chordata (Gobiidae) & $\begin{array}{l}\text { Neogobius melanostomus } \\
\text { (Pallas, 1814) }\end{array}$ & Round goby & Ponto-Caspian region \\
\hline 62. & Chordata (Gobiidae) & $\begin{array}{c}\text { Ponticola kessleri (Günther, } \\
\text { 1861) }\end{array}$ & $\begin{array}{c}\text { Bighead goby, Kessler's } \\
\text { goby }\end{array}$ & Ponto-Caspian region \\
\hline 63. & Chordata (Centrarchidae) & $\begin{array}{c}\text { Lepomis gibbosus (Linnaeus, } \\
1758)^{*}\end{array}$ & Pumpkinseed, sun bass & North America \\
\hline 64. & Chordata (Centrarchidae) & $\begin{array}{l}\text { Micropterus salmoides } \\
\text { (Lacepède, 1802) }\end{array}$ & Largemouth bass & North America \\
\hline
\end{tabular}

\section{Results}

3.1. Invasive Alien Species in Europe' App Early Testing (2016-2017)

3.1.1. Information and Field Testing Campaigns

A total of 11 information and field testing campaigns were performed during 2016-2017. Of them, nine campaigns were held in Bulgaria, one in Romania and one in Serbia. In total, 52 field sites (50 in Bulgaria, one in Romania and one in Serbia) were visited. The campaigns involved 240 participants, including the leading scientists.

\subsubsection{Species Recorded}

Five IAS of EU concern and 19 observations were recorded during this period (Table 2, Figure 1). Other IAS of DRB concern, such as Lepomis gibbosus (16 sites), Corbicula fluminea (10 sites), Gambusia holbrooki (six sites), Carassius gibelio (five sites), Ameiurus melas, Melanoides tuberculata and Sinanodonta woodiana (each at one site), were observed during the field testing but their recording was not possible with IASapp during this testing period because of its limited functionalities regarding species of regional concern. 
Table 2. Invasive alien species of EU concern recorded with 'Invasive Alien Species in Europe' app (IASapp), during the field testing in the Lower Danube Region in 2016-2017.

\begin{tabular}{|c|c|c|c|c|c|}
\hline No. & $\begin{array}{l}\text { Phylum (Lower } \\
\text { Taxon) }\end{array}$ & $\begin{array}{l}\text { IAS of EU } \\
\text { Concern }\end{array}$ & Number of Sites & $\begin{array}{c}\text { Number of } \\
\text { Records with } \\
\text { IASapp (Number } \\
\text { of Specimens) }\end{array}$ & Comments \\
\hline 1 & $\begin{array}{l}\text { Arthropoda } \\
\text { (Decapoda) }\end{array}$ & $\begin{array}{c}\text { Eriocheir sinensis H. } \\
\text { Milne Edwards, } \\
1853\end{array}$ & 1 & $2(1)$ & $\begin{array}{l}\text { Bulgaria-dead specimen } \\
\text { collected 5-6 years ago, } \\
\text { observed mounted as } \\
\text { decoration on the wall of a } \\
\text { fish shop }\end{array}$ \\
\hline 2 & $\begin{array}{l}\text { Arthropoda } \\
\text { (Decapoda) }\end{array}$ & $\begin{array}{l}\text { Faxonius limosus } \\
\text { (Rafinesque, 1817) }\end{array}$ & 2 & $4(2)$ & Bulgaria \\
\hline 3 & $\begin{array}{l}\text { Chordata } \\
\text { (Cyprinidae) }\end{array}$ & $\begin{array}{c}\text { Pseudorasbora parva } \\
\text { (Temminck and } \\
\text { Schlegel, 1846) }\end{array}$ & 8 & $10(28)$ & Bulgaria \\
\hline 4 & $\begin{array}{c}\text { Chordata } \\
\text { (Odontobutidae) }\end{array}$ & $\begin{array}{l}\text { Perccottus glenii } \\
\text { Dybowski, } 1877\end{array}$ & 2 & $2(9)$ & Bulgaria \\
\hline 5 & Chordata (Reptilia) & $\begin{array}{l}\text { Trachemys scripta } \\
\text { (Thunberg in } \\
\text { Schoepff, 1792) }\end{array}$ & 1 & $1(2)$ & $\begin{array}{c}\text { Tăbăcărie Park and Lake, } \\
\text { Constanța, Romania }\end{array}$ \\
\hline
\end{tabular}

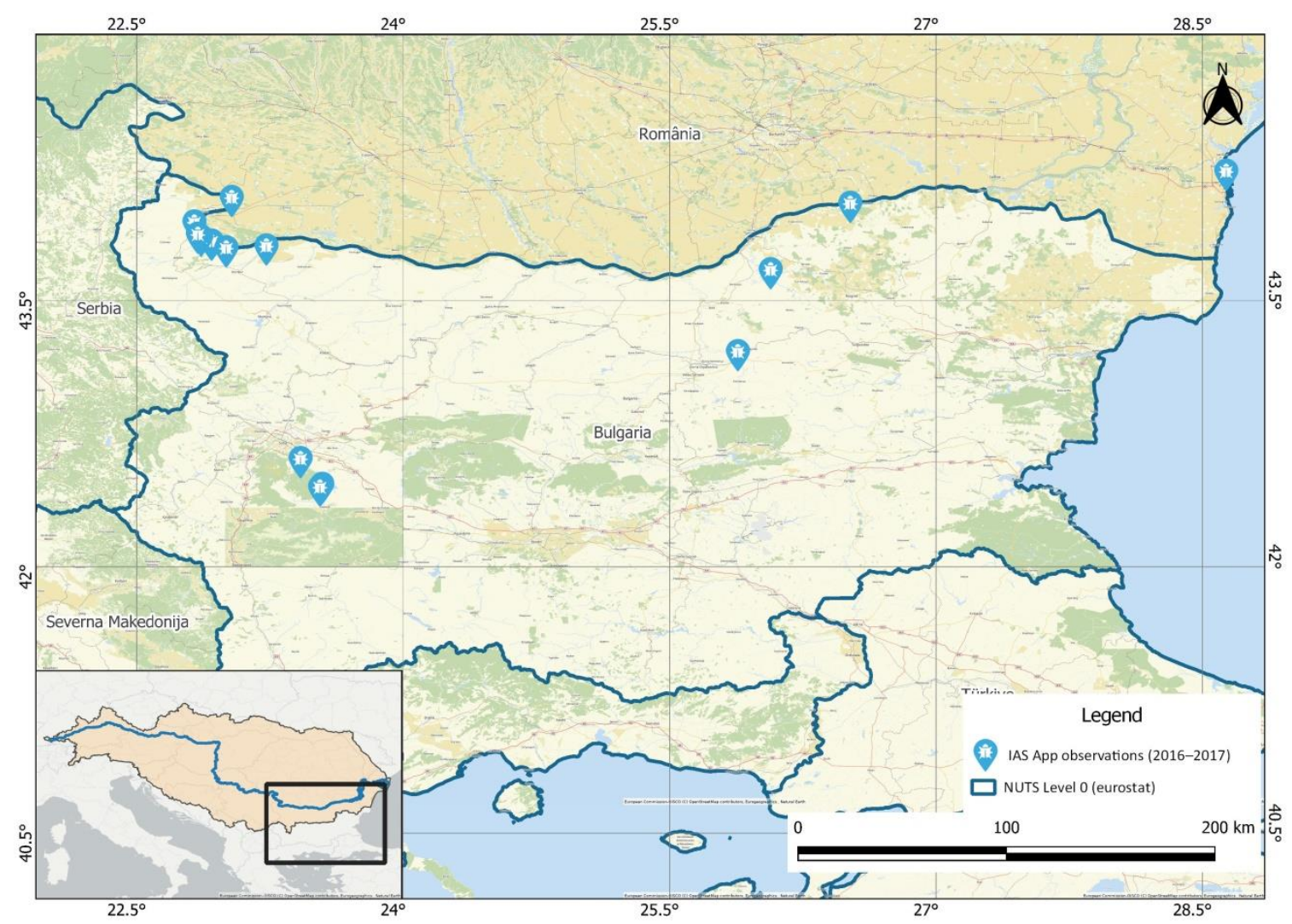

Figure 1. Observations recorded with 'Invasive Alien Species in Europe' app in the Lower Danube Region in $2016-2017$.

\subsubsection{Feedback of Participants}

1. Information about the stakeholders

A total of 59 feedback forms (35 from Bulgaria, 19 from Romania and five from Serbia) were filled in and submitted by participants. Some participants sent feedback and 
comments by email or gave information about issues encountered and suggestions for improvement during the discussions after the testing. The participants that filled in the feedback forms belonged to the following groups of stakeholders: researchers in the area of aquatic biology and ecology (Bulgaria) (5); GIS experts (Bulgaria) (1); MSc students in the area of applied hydrobiology and aquaculture (Bulgaria) (6); students in the area of plant protection and agriculture (Bulgaria) (23); students and one PhD student in ecology and biology (Romania) (15); researchers in the area of biology and environmental studies, and graphic design (Romania) (3); freelancers (Romania) (1); and researchers in the area of freshwater biology and ecology (Serbia) (5).

2. Knowledge of the participants on IAS and IAS Regulation

Most of the participants knew about IAS and some of the problems they cause. However, about $20 \%$ of the participants, who filled the feedback forms, mainly students, had not heard about IAS Regulation. About $10 \%$ of participants could not mention any IAS of EU concern, while about $20 \%$ could not mention any other IAS. The students mostly indicated species about which they heard during the training or observed in the field. Other participants, who did not complete the feedback forms but participated in the discussions, were also not aware of IAS Regulation and of the list of species of EU concern.

\section{Feedback on IASapp}

The participants gave their opinion about the appearance of the app, its content, navigation, functionality, speed, stability and bugs, technical issues and other issues (e.g., ethical issues), usefulness and rating of the app. Based on their feedback, the following conclusions were drawn:

(1) Necessity of extending the language options.

Broader language options were required by the stakeholders. Almost all participants from the three countries asked for translation in native languages-Bulgarian, Romanian and Serbian. Many of them experienced difficulties in using the application in English.

(2) Necessity of extending the species list.

Because of the low number of the IAS of EU concern present in the three countries, many of the participants highlighted the limitations of the IASapp and the need for extending the list of species included in order to make its use more efficient in the region. There were several suggestions in this regard:

- $\quad$ Regional adaptation of IASapp by including the IAS relevant to the DRB;

- Extending of the list by including alert species at the EU/Danube Region level, for the purposes of early detection; and

- Possibility to report an observation of a new/unknown species that might be a new IAS.

(3) Recommended improvement of species descriptions, identification keys and additional illustrations.

(4) Recommended extension and improvement of the app navigation options and functionality.

Several features were recommended by the stakeholders to facilitate navigation, search and other functions of the IASapp:

- $\quad$ Search engines for visualizing the species' distribution maps and for reporting an observation;

- $\quad$ Extending the search options for the species list;

- Re-arranging and reducing the items in the main menu;

- $\quad$ Adding saving options for the records; and

- Fixing problems with registering the geographic location.

(5) Recommended improvement of technical features of the IASapp (fixing bugs, making it compatible with a wider range of phones, etc.).

(6) Necessity of raising public awareness on IAS in the region. 


\subsection{Update of IASapp for the Danube River Basin}

A new functionality of the app was developed, which provided the user with the possibility of sending observations of the 64 IAS of concern to the DRB. The option is available whenever the smartphone device is located in the Danube Region (with the location functionality turned on). After installing the IASapp and downloading the Local Species Catalogue, the list of local species becomes available in the Invasive species section, together with the IAS of EU concern. The software and factsheets of all 130 species (66 IAS of EU concern and 64 IAS of DRB concern) were translated and made available into native languages of the study region-Bulgarian, Romanian and Serbian.

\subsection{Testing of the Updated App during JDS4}

Two information campaigns related to the use of IASapp for monitoring purposes in the DRB were held during JDS4 - one in Serbia (July 2019, Belgrade) and one in Bulgaria (4 October 2019, Ruse). The participants represented various stakeholder groups, including the JRC, Bulgarian and Serbian research institutions, plus universities, teachers and students, regional authorities and public companies.

A total of 14 aquatic IAS was recorded with the updated IASapp during JDS4 (2019). In Bulgaria, 56 records of 12 IAS were made at 31 sites out of 82 sites sampled in the Danube River, Danube tributaries and adjacent canals, lakes and reservoirs. In Serbia, 17 records of four IAS were made (Table 3, Figure 2). Five of the recorded species (one plant, one crayfish and three fish species) are the IAS of EU concern, while nine species are the IAS of concern to the DRB. Twelve species are alien for Europe; Dreissena rostriformis bugensis is alien for the DRB and D. polymorpha is translocated (Table 3).

Table 3. Invasive alien species of EU and Danube River Basin (DRB) concern recorded with IASapp in the Lower Danube Region during JDS4 in 2019.

\begin{tabular}{|c|c|c|c|c|}
\hline No. & Species & Number of Sites & $\begin{array}{l}\text { Number of Records with } \\
\text { IASapp (Number of } \\
\text { Specimens) }\end{array}$ & Comments \\
\hline & & IAS of EU concern & & \\
\hline 1 & $\begin{array}{l}\text { Elodea nuttallii (Planch.) H. } \\
\text { St. John (Plantae) }\end{array}$ & 1 & 1 & Serbia \\
\hline \multirow{2}{*}{2} & \multirow{2}{*}{ Faxonius limosus } & 4 & $6(21)$ & Bulgaria \\
\hline & & 8 & $8(69)$ & Serbia \\
\hline 3 & Pseudorasbora parva & 6 & $6(14)$ & Bulgaria \\
\hline 4 & Perccottus glenii & 3 & $3(6)$ & Bulgaria \\
\hline 5 & Lepomis gibbosus & 2 & $2(6)$ & Bulgaria \\
\hline \multicolumn{5}{|c|}{ IAS of DRB concern } \\
\hline 6 & Corbicula fluminea & 17 & $17(>60)$ & Bulgaria \\
\hline 7 & Dreissena polymorpha & 3 & $3(270)$ & Serbia \\
\hline 8 & $\begin{array}{c}\text { Dreissena rostriformis } \\
\text { bugensis }\end{array}$ & 2 & $2(256)$ & Bulgaria \\
\hline \multirow{2}{*}{9} & \multirow{2}{*}{ Sinanodonta woodiana } & 13 & $13(51)$ & Bulgaria \\
\hline & & 5 & $5(44)$ & Serbia \\
\hline 10 & Pectinatella magnifica & 2 & $2(11)$ & Bulgaria \\
\hline 11 & Carassius gibelio & 2 & $2(10)$ & Bulgaria \\
\hline 12 & Ctenopharyngodon idella & 1 & $1(1)$ & Bulgaria \\
\hline 13 & $\begin{array}{l}\text { Hypophthalmichthys } \\
\text { molitrix }\end{array}$ & 1 & $1(3)$ & Bulgaria \\
\hline \multirow[t]{2}{*}{14} & Ameiurus melas & 1 & $1(5)$ & Bulgaria \\
\hline & Total: & & 73 & \\
\hline
\end{tabular}




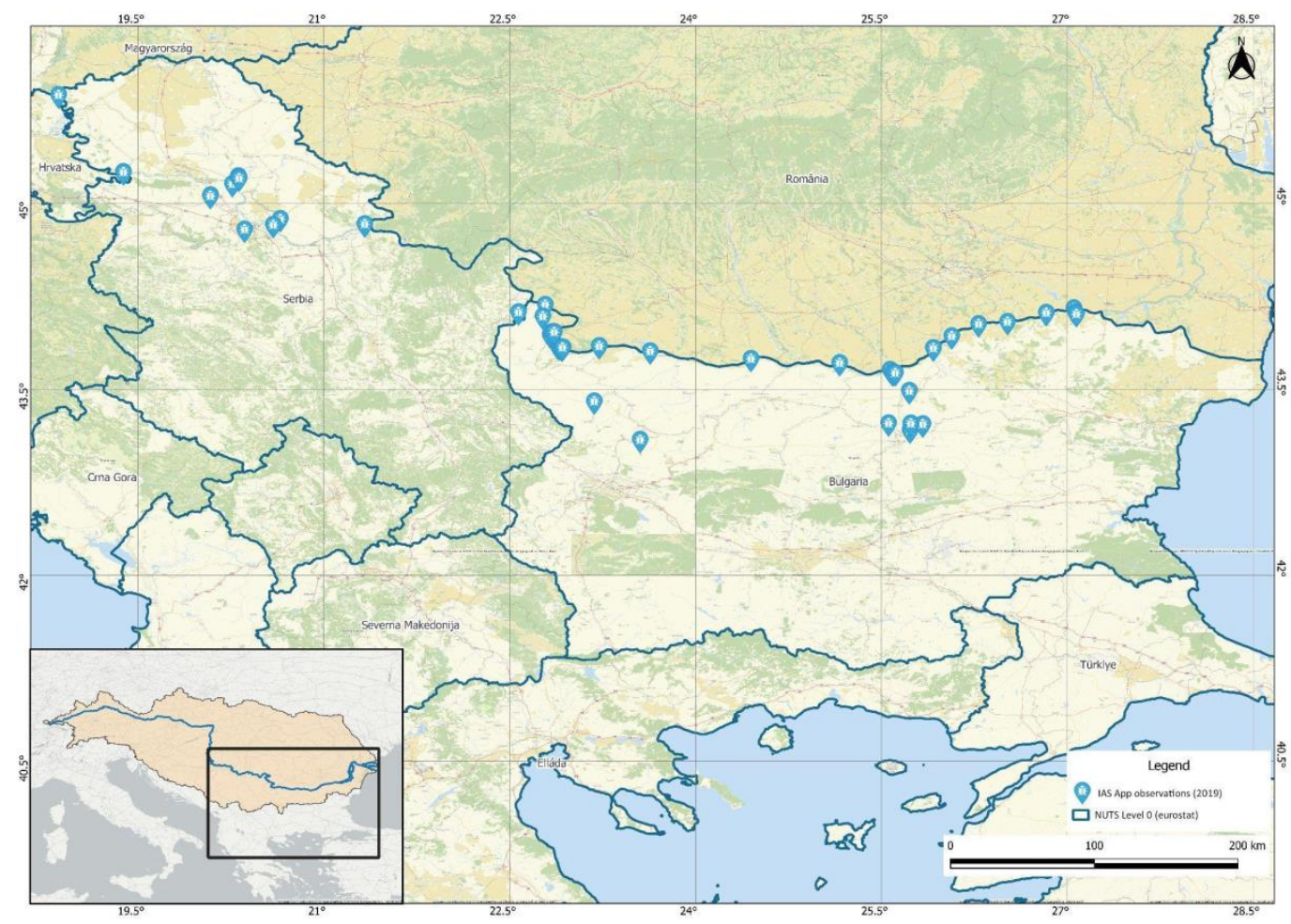

Figure 2. Observations recorded with IASapp in the Lower Danube Region during JDS4 (2019).

\section{Discussion}

During the testing in 2016-2017, the list of the IAS of EU concern contained 37 species, of them 14 plants, seven invertebrates and 16 vertebrates [28]. The review of literature and available data showed that 10 IAS of EU concern from this first list have been reported in the region (Bulgaria, Romania and Serbia): Cabomba caroliniana A. Gray, Heracleum sosnowskyi Manden., Eriocheir sinensis, Faxonius limosus, Procambarus virginalis Lyko, 2017, Perccottus glenii, Pseudorasbora parva, Trachemys scripta, Myocastor coypus Molina, 1782, and Procyon lotor Linnaeus, 1758 [21,59-65]. Six of them have been found occasionally and/or had limited distribution, which makes them difficult for recording through the involvement of citizens using IASapp. Cabomba caroliniana and H. sosnowskyi were reported only at single sites in Romania and subsequently their presence has not been confirmed [61,66]. Since 1995 E. sinensis has been found occasionally in the Lower Danube River (Serbia and Bulgaria) and Danube Delta (Romania) [22,67]. Procambarus virginalis is found only in a seminatural pond in Băile Felix, near Oradea, Romania [62]. Procyon lotor has single records in Serbia and Romania, the species has not been reported yet from Bulgaria $[64,68]$. Myocastor coypus is rarely found in the DRB in Bulgaria and Romania [64,69], but in the Serbian section of the Danube River, between 1171 and $1150 \mathrm{rkm}$, it can be commonly observed [70]. With the further update of the list of the IAS of EU concern in 2017 and 2019 , the number of species has become 66, of which 36 plants, eight invertebrates and 22 vertebrates $[29,30]$. In total, 13 of the newly added IAS of EU concern have been reported from the region, which included eight plants: Ailanthus altissima (Mill.) Swingle, Asclepias syriaca L., Elodea nuttallii, Heracleum mantegazzianum Sommier and Levier, Humulus japonicus/Humulus scandens, Impatiens glandulifera Royle, Myriophyllum aquaticum (Vell.) Verdc. and Pennisetum setaceum (Forssk.) Chiov. [60,63,66,71-74]; one fish: L. gibbosus; two birds: Alopochen aegyptiacus (Linnaeus, 1766) and Threskiornis aethiopicus (Latham, 1790); and two mammals: Nyctereutes procyonoides (Gray, 1834) and Ondatra zibethicus (Linnaeus, 1766) $[18,60,64,65,75,76]$. Myriophyllum aquaticum was reported from only one site-Lake Peţea, in Romania, which is currently drained [66].

Six aquatic IAS of EU concern were recorded in natural and seminatural habitats during the IASapp testing in the Lower Danube Region: E. nuttallii, F. limosus, L. gibbosus, P. 
glenii, P. parva and T. scripta. For the purposes of testing, two records were made on a dead specimen of E. sinensis caught 5-6 years ago in the Bulgarian stretch of the Danube River. The observation, which is the second record of the species in Bulgaria [22], was recorded using the geographic coordinates of the fish shop where the specimen was mounted as decoration on the wall. The number of recorded species represents $30 \%$ of all IAS in the EU list of concern currently present in the region and $100 \%$ of all aquatic ones present in the region (not counting semiaquatic mammals).

The highest number of records was made on P. parva, which was found in the Danube River, in some tributaries, adjacent canals and marshes during both testing periods in Bulgaria (Tables 2 and 3). This was expected as the species is widespread in the region $[18,61,64,77-79]$. Faxonius limosus was the second frequently recorded species in the testing, especially during JDS4 (2019) (Tables 2 and 3). It was also the most abundant species in this period-21 specimens at four sites, mainly in the tributaries, were recorded with IASapp in Bulgaria and 69 specimens at eight sites, mainly in the Danube River, in Serbia. This species is a comparatively recent invader in the Lower Danube Region. Its first record from the Danube River in Serbia was in 2002 [59,80], and in 2008, the species was reported from the Romanian Danube [81]. In Bulgaria, the first reports were in 2015 from the Danube tributaries [82]. Perccottus glenii was recorded during both testing periods in the canal system and Srebarna Lake in Bulgaria. The first records of this species from the Lower Danube were in 2001 from a fish pond in Serbia [83], and from the Suceava River in Romania [84]. In the period 2003-2005, the species was reported from the Danube River in Serbia [85], Romania [86] and Bulgaria [13,15]. Currently, it is spread in the DRB in Bulgaria and Serbia [18,87], and in 14 out of 42 counties in Romania [61,64]. Single records were made on T. scripta in Tăbăcărie Park and Lake, in Constanța, Romania, during the first testing period, and on E. nuttallii in Serbia during the second testing period (Tables 2 and 3). Lepomis gibbosus was found in both testing periods in Bulgaria (in the Danube River, tributaries and reservoirs), with higher frequency of records in 2016-2017 (at 16 sites). However, as the species was included in the list of IAS of EU concern with the second update (2019) [30], its recording with IASapp was possible only during JDS4 (Table 3). The species is common in the region $[18,64,75,88]$.

The recording of the IAS of concern to the DRB using the IASapp was possible only after the regional update of the app in the second testing period. Nine species were recorded in Bulgaria and Serbia during JDS4, seven of them were alien to Europe ( $28 \%$ of all alien species for Europe listed from the DRB), while one was alien (D. rostriformis bugensis) and one was translocated (D. polymorpha) to the DRB (Table 3). The mussels C. fluminea (found at 17 sites in Bulgaria) and S. woodiana (at 13 sites in Bulgaria and 5 sites in Serbia) were the most frequently recorded and most abundant species in the Danube River and the tributaries. For comparatively short periods after their first reporting in the Lower Danube River, both species have become widespread in the region [19,25,26,89-92]. The first living specimens of $C$. fluminea were recorded in the Danube River in the Iron Gates area, at Berzasca, Romania, in 1997 [93], then at Oresac, Serbia, in 1998 [91], and at Vadu Oii, Romania, in 1999 [25,94]. In Bulgaria, the species was first reported in 2001 [95]. Sinanodonta woodiana was firstly recorded in 1979 in fish ponds at Cefa-Oradea, Romania, which is also the first record for Europe [89,96]. After 1998, this species has rapidly spread in the Danube River and its tributaries in Serbia [90], Romania [89] and Bulgaria [92,97]. The third mussel D. rostriformis bugensis was recorded at two sites in Bulgaria, one in the Danube River and one in Ogosta Reservoir, during the testing. Although a recent invader, this species is common now in the Lower Danube River. It was reported for the first time at Cernavodă, Romania, in 2004 [98], and in the following period, 2005-2010, from the entire Serbian-Romanian sector $[14,99,100]$. Pectinatella magnifica was recorded at two sites in Bulgaria during the testing, which are the first records of this species in the Bulgarian shoreline zone of the Danube River [101]. The occurrence of P. magnifica has been reported from the Hungarian-Romanian sector of the Danube River in 2013 [102]. During JDS4, A. melas was recorded with IASpp at only one site-the outflow canal of Malak Preslavet 
Lake in Bulgaria. In 2005, the species was reported for the first time from a side channel and Savsko Jezero Lake (near Belgrade), in the Serbian sector [103], as well as from the main channel near Drobeta Turnu Severin, in the Romanian sector of the Danube River [86]. In Bulgaria, A. melas was found for the first time in Srebarna Lake in 2013 [104]. The Asian carps (C. gibelio, Ctenopharyngodon idella and Hypophthalmichthys molitrix) were recorded at single sites in the Danube River in Bulgaria during the testing in 2019. Carassius gibelio was recorded also from a tributary-the Archar River. This species was encountered at five sites during the first testing period (2016-2017), but as in the case with the other species of DRB concern, its recording was not possible before the update of the IASapp.

The timely access to spatial data on IAS is a key aspect for their successful management $[105,106]$. The improved functionality and usability of IASapp enables the use of the collected records for science and policy-making at EU, regional and national levels. Currently, IASapp allows users to report the presence of the 66 IAS of EU concern and 64 IAS of DRB concern, when located in that area. For each species, IASapp provides: summary factsheets, exemplary pictures and links to further information [50]. The software and factsheets are already available in the languages of the countries in the region: Bulgarian, Romanian and Serbian. The data collected by users includes date and time, geospatial location and abundance, together with the upload of one or more pictures that help to validate the information sent with the report. This information is essential for the early detection and rapid response and for actions taken under IAS Regulation and national IAS policies. Additionally, the information generated through IASapp could supplement Member States Competent Authorities surveillance systems. The data on species distribution can be further used for the reporting on the IAS Regulation [107]. For example, the data collected during the first testing period (2016-2017) in Bulgaria were included in the first national report, in line with Article 24(1) of IAS Regulation [108]. Furthermore, the data obtained with IASapp by citizens can complement national and regional monitoring programs, such as JDS4. Thus, the data can contribute to the implementation of the DRB Management Plan [32] and the national river basin management plans in the Danube Region, in compliance with the EU Water Framework Directive [33], as well the Natura 2000 site management strategies along the Danube River, under Habitats Directive [109]. Finally, the IAS citizen science data can be used in the frame of various scientific and management projects. Up-to-date, accurate and reliable data on the IAS distribution are used in predictive modeling, risk modeling and risk mapping, impact assessment and risk assessment, climate matching and other activities, underpinning management strategies for biological invasions $[105,106]$.

Some of the IAS of EU concern in the region (e.g., E. nuttallii and other plants, plus T. scripta) and IAS of DRB concern (e.g., C. fluminea and S. woodiana) are easily recognizable, there is no need for special equipment to observe and photograph them, and often there are no accessibility constraints for the involvement of citizen scientists in their monitoring and reporting. Other IAS (crayfish, fish, semiaquatic mammals) need special equipment to be caught (fishing rods, nets, traps, boats) and/or are difficult to be observed by the general public. However, their observation in nature and recording with IASapp by specific groups of stakeholders, such as relevant competent authorities (environment, forestry, fishery and aquaculture), biodiversity experts, students, anglers and hunters, should not pose any difficulties. The identification of certain IAS of DRB concern (e.g., Ponto-Caspian crustaceans) is generally considered difficult by non-professionals. In such cases, the factsheets and pictures provide essential information to guide the IASapp users towards a more precise identification of the observed species. The following information is included for each species: species appearance, confounding traits with similar species, type of habitat occupied, behavior, invasion history, origin and links to access additional information [50]. The involvement of a broader range of stakeholder groups in the training and using of the IASapp will give possibility to fully harvest the new functionality relevant to the DRB.

The results of the study revealed that although all participants showed interest in using the IASapp, there was not enough knowledge about IAS and IAS Regulation among 
all groups of stakeholders in the three countries in the Lower Danube Region. More than $20 \%$ of the participants who filled feedback forms and participated in the discussions during the information and field testing campaigns had not heard about IAS Regulation and could not mention any IAS. These results are supported also by the fact that local people already had knowledge about the occurrence of P. magnifica and E. sinensis recorded for the first and second time, respectively, from Bulgaria, but they were not aware about the necessity of reporting this to institutions. The recorded dead specimen of E. sinensis had been caught 5-6 years ago in the Bulgarian stretch of the Danube River by local fishermen and used for decoration of a fish shop [22], while other fishermen had experienced regular clogging of the nets with P. magnifica in the previous two years before the records made in 2019 [101]. One might argue that, if the general public would have been timely informed about IAS and the availability of tools like IASapp, the competent institutions might probably have received this information much earlier. One of the aims of the IASapp is to allow citizens to become involved in the IAS monitoring and reporting and thus raise awareness of the IAS issues [50]. To achieve this, it is essential both to establish close collaboration with existing stakeholder groups and to create new citizen science groups [46,50]. Based on the experience of using two smartphone applications for the IAS recording in Europe [46], several recommendations for engaging the public in recording IAS under different projects are proposed. It is highlighted, among others, the necessity of: (1) taking into account the target audience and understanding the needs and motivations of recorders; (2) investing in volunteer management and interaction with users (e.g., through feedback on survey campaigns and control actions); and (3) communicating to users why and how their records can help. Motivating participants and retaining their interest over time should be carefully considered [50]. It is very important to provide opportunities, such as training and mentoring for stakeholders to increase their skills and expertise [41]. Furthermore, the appropriate forms of engagement need to be considered at an early stage. In the case of IASapp, this may include species validation by experts and citizen scientists, and interaction of the public servants and decision makers at the national and regional level, depending on the scale of the actual implementation of the IAS monitoring and management [50]. During both stages of the IASapp testing, considerable time and efforts were invested in performing the information campaigns. Information about IASapp and technical details about its installation and usage, as well as information about IAS, such as characteristic features, pathways of introduction, distribution and impact was presented. In addition, information about prevention and management measures under the IAS Regulation, and about possibilities of applying citizen science in IAS monitoring in the DRB was provided.

The feedback from stakeholders was very useful for the development and start of the follow-up citizen science initiatives on IAS. The use of IASapp could be further developed by conducting targeted information and publicity campaigns. For example, information campaigns can attract partners from the education system (schools, universities) within the Danube Region (but not exclusively). This would provide educators with a friendly platform for field applications with students, while students are offered the opportunity to become involved in a high-impact and meaningful real-life monitoring action. Similarly, publicity campaigns targeting the tourism sector might lead to partnerships with key stakeholders (e.g., official tourism offices or programs) which could be highly beneficial for expanding the range of users of IASapp and to increase public awareness regarding IAS. Therefore, further and constant communication with various groups of stakeholders is crucial for increasing the effectiveness of using the IASapp in the Danube Region for different purposes such as early detection, monitoring and raising awareness.

\section{Conclusions}

The results of the present pilot study show that the 'Invasive Alien Species in Europe' smartphone application could be an effective tool for collecting data on IAS in the Danube Region. Currently, the IASapp allows users to report the presence of the 66 IAS of EU 
concern. During the IASapp testing, six aquatic IAS of EU concern were recorded in natural and seminatural habitats in the Lower Danube: E. nuttallii, F. limosus, L. gibbosus, P. glenii, P. parva, and T. scripta and E. sinensis. The number of the recorded species represents $30 \%$ of all IAS in the EU list of concern currently present in the region and $100 \%$ of all aquatic ones present in the region (not counting semiaquatic mammals).

The developed new functionality and update of the IASapp for the DRB has enabled recording observations of 64 species of DRB concern, including 43 aquatic invertebrates and 21 fish species. Of them, nine species were recorded in Bulgaria and Serbia during the testing, including seven alien species for Europe, which represents $28 \%$ of all alien species for Europe from the DRB listed in the app. The availability of the software and of the species factsheets in native languages-Bulgarian, Romanian and Serbian-along with the extended and improved navigation options, functionality and technical characteristics of the IASapp, has made it a more user-friendly and helpful IAS monitoring tool for the region.

With the new functionality provided, IASapp may help filling some of the gaps in data availability regarding the IAS in the Danube Region and improving the quantity and quality of data generated by citizen science. The citizen science data collected with IASapp (pictures, date and time of observation, geospatial location and abundance) are essential for early detection and rapid response purposes and actions taken under IAS Regulation, as well as relevant national and regional IAS policies. The data about the IAS distribution can complement different national and regional monitoring programs, as JDS4, and be further used in the framework of various research projects and management strategies in the region.

Finally, the updated IASapp could have an important role in increasing the citizens' awareness on IAS and their impact, as well as in enlarging the participation and output of citizen science in IAS early detection, monitoring and reporting in the Danube Region. Therefore, the constant communication with existing stakeholder groups and establishment of new citizen science groups is crucial for increasing the effectiveness of using the IASapp in the Danube Region and tackling the IAS issues.

Author Contributions: Conceptualization, T.T., M.P., D.C., R.T., S.S. and A.C.C.; Methodology, T.T., M.P., D.C., M.T. and R.T.; Software, I.M. and F.A.S.; Validation, E.G., C.L.-C. and K.T.; Formal Analysis, T.T., M.P., N.M., D.C., M.T., R.T., I.B., Z.H., C.P. and F.S.; Investigation, T.T., M.T., R.T., M.K., I.B., Z.H., K.I., M.P., N.M., D.C., F.S. and C.P.; Resources, A.C.C., S.S., E.G., I.M., C.L.-C., F.A.S. and K.T.; Data Curation, I.M. and F.A.S.; Writing-Original Draft Preparation, T.T., M.P. and D.C.; Writing-Review and Editing, All authors; Supervision, A.C.C. and S.S. All authors have read and agreed to the published version of the manuscript.

Funding: This research was funded by the EU Horizon 2020 Framework Programme under the Alien CSI Cost Action CA17122, co-funded by the National Science Fund of Bulgaria, Project KP-06COST-13/06.08.2019, and by the European Commission, Joint Research Centre, Danube-IASapp Project (2016-2017), Contract No. 650084. T.T., M.T., R.T., Z.H., I.B., K.I. and M.K. (Investigation) were additionally supported by the Enterprise for Management of Environmental Protection Activities in Bulgaria, the Ministry of Environment and Water, Contract No. 13063/03.07.2019, and the Ministry of Education and Science of Bulgaria (Agreement No. DO-230/06-12-2018). M.P. and N.M. (Formal Analysis and Writing-Review and Editing) were additionally supported by the Ministry of Education, Science and Technological Development of Republic of Serbia, Contract No. 451-03-9/2021-14/200007. The IASapp updates (Software, I.M. and F.A.S.; Validation, E.G., C.L.-C. and K.T.; Resources, A.C.C., S.S., E.G., I.M., C.L.-C., F.A.S. and K.T.; Data Curation, I.M. and F.A.S., Supervision, A.C.C. and S.S.) were carried out in the context of the JRC Institutional Proof of Concept Projects 'IAS Europe app: engaging citizens in alien species surveillance' and 'Citizen Science data supporting Invasive Alien Species policy in Europe'. The publication of this paper was funded by the National Science Fund of Bulgaria, Project KP-06-COST-13/06.08.2019.

Institutional Review Board Statement: The research projects of IBER-BAS, under which the present study was conducted, were approved by the Scientific Council and included in the scientific plan of 
IBER-BAS according to the following protocols: No. 25/25.10.2016, 55/20.11.2018, 6/14.06.20019, 8/20.09.2019 and 9/18.10.2019.

Informed Consent Statement: Informed consent was obtained from all subjects involved in the study. The completion of the feedback questionnaire by the participants during the testing of the IASapp was optional and the data filled in were used in the analyses only after receiving the participants' agreement.

Data Availability Statement: The 'Invasive Alien Species in Europe' app validated reports are freely available from and can be reused with no limitations, see also https: / data.jrc.ec.europa.eu/dataset/ jrc-citsci-cs-jrc-ias (accessed on 10 September 2021).

Acknowledgments: The authors acknowledge the support and coordination of the International Commission for the Protection of the Danube River (ICPDR) during Joint Danube Survey 4 (JDS4). The authors also acknowledge the assistance and support of the following institutions during the IASapp testing: Regional Inspectorate of Environment and Water (RIEW)-Montana, RIEW—Ruse, Executive Agency of Fishery and Aquaculture (EAFA) - Vidin, Department of General and Applied Hydrobiology at Biological Faculty of Sofia University (BF-SU), Department of Zoology and Anthropology at BF-SU, Faculty of Agriculture at University of Forestry, Sofia, and Sofia Zoo (Bulgaria); Faculty of Biology at University of Belgrade (Serbia); and Faculty of Natural and Agricultural Sciences at Ovidius University Constanta and Oceanic Club NGO (Romania). The authors express their gratitude to the following persons for the collaboration: Alexander Kotsev from JRC; Milen Metodiev from EAFA-Vidin; Anelia Nikolova from RIEW—Ruse; Eliza Uzunova, Lyubomir Kenderov and Atanas Grozdanov from BF-SU; Vladimir Vladimirov from IBER-BAS; and Katerina Zareva-Simeonova, Maria Tereza Kortes, and Radko Sertov from Sofia Zoo. The authors thank Mario Vichev, Georgi Angelov, Lyubomir Krasimirov and Yordan Yordanov for the help during the field testing. The authors also thank the two anonymous reviewers for their comments which helped to improve the paper.

Conflicts of Interest: The authors declare that they have no known conflict of interests or personal relationships that could have appeared to influence the work reported in this paper.

\section{References}

1. Pyšek, P.; Hulme, P.E.; Simberloff, D.; Bacher, S.; Blackburn, T.M.; Carlton, J.T.; Dawson, W.; Essl, F.; Foxcroft, L.C.; Genovesi, P.; et al. Scientists' warning on invasive alien species. Biol. Rev. 2020, 95, 1511-1534. [CrossRef]

2. Vilà, M.; Hulme, P.E. Impact of Biological Invasions on Ecosystem Services; Springer International Publishing: Cham, Switzerland, 2017 ; p. 354.

3. Cuthbert, R.N.; Pattison, Z.; Taylor, N.G.; Verbrugge, L.; Diagne, C.; Ahmed, D.A.; Leroy, B.; Angulo, E.; Briski, E.; Capinha, C.; et al. Global economic costs of aquatic invasive alien species. Sci. Total Environ. 2021, 775, 145238. [CrossRef]

4. Diagne, C.; Leroy, B.; Vaissière, A.C.; Gozlan, R.E.; Roiz, D.; Jarić, I.; Salles, J.M.; Bradshaw, C.J.; Courchamp, F. High and rising economic costs of biological invasions worldwide. Nature 2021, 592, 571-576. [CrossRef]

5. Kettunen, M.; Genovesi, P.; Gollasch, S.; Pagad, S.; Starfinger, U.; ten Brink, P.; Shine, C. Technical Support to EU Strategy on Invasive Alien Species (IAS)_Assessment of the Impacts of IAS in Europe and the EU. Final Module Report for the European Commission; Institute for European Environmental Policy (IEEP): Brussels, Belgium, 2009; p. 44.

6. Institute for European Environmental Policy (IEEP). Available online: https:/ /ieep.eu/ (accessed on 26 June 2021 ).

7. Haubrock, P.J.; Turbelin, A.J.; Cuthbert, R.N.; Novoa, A.; Taylor, N.G.; Angulo, E.; Ballesteros-Mejia, L.; Bodey, T.W.; Capinha, C.; Diagne, C.; et al. Economic costs of invasive alien species across Europe. NeoBiota 2021, 67, 153-190. [CrossRef]

8. Bij de Vaate, A.; Jazdzewski, K.; Ketelaars, H.A.M.; Gollasch, S.; Van der Velde, G. Geographical patterns in range extension of Ponto-Caspian macroinvertebrate species in Europe. Can. J. Fish. Aquat. Sci. 2002, 59, 1159-1174. [CrossRef]

9. Arbaciauskas, K.; Semenchenk, V.; Grabowski, M.; Leuven, R.S.; Paunovic, M.; Son, M.O.; Csányi, B.; Konopacka, A.; Nehring, S.; van der Velde, G.; et al. Assessment of biocontamination of benthic macroinvertebrate communities in European inland waterways. Aquat. Invasions 2008, 3, 211-230. [CrossRef]

10. Panov, V.E.; Alexandrov, B.; Arbačiauskas, K.; Binimelis, R.; Copp, G.H.; Grabowski, M.; Lucy, F.; Leuven, R.S.; Nehring, S.; Paunović, M.; et al. Assessing the risks of aquatic species invasions via European Inland waterways: From concepts to environmental indicators. Integr. Environ. Assess. Manag. 2009, 5, 110-126. [CrossRef]

11. Tittizer, T.; Schöll, F.; Banning, M.; Haybach, A.; Schleuter, M. Aquatische neozoen im makrozoobenthos der Binnenwasserstraßen Deutschland [Aquatic neozoan invertebrates in the inland waterways of the Federal Republic of Germany]. Lauterbornia 2000, 39, 1-72.

12. Puky, M.; Reynolds, J.; Schád, P. Native and alien decapoda species in Hungary: Distribution, status, conservation importance. Bull. Fr. Pêche Piscic. 2005, 376-377, 553-568. [CrossRef] 
13. Jurajda, P.; Vassilev, M.; Polacik, M.; Trichkova, T. First record of Perccottus glenii (Perciformes: Odontobutidae) in the Danube River in Bulgaria. Acta Zool. Bulg. 2006, 58, 279-282.

14. Hubenov, Z.; Trichkova, T. Dreissena bugensis (Mollusca: Bivalvia: Dreissenidae): New invasive species to the Bulgarian malacofauna. Acta Zool. Bulg. 2007, 59, 203-210.

15. Polačik, M.; Trichkova, T.; Janáč, M.; Vassilev, M.; Jurajda, P. The ichthyofauna of the shoreline zone in the longitudinal profile of the Danube River, Bulgaria. Acta Zool. Bulg. 2008, 60, 77-88.

16. Puky, M.; Ács, É.; Bódis, E.; Borza, P.; Kiss, K.T.; Tóth, A. Invasive algae, plant, bivalve and crustacean species along the Hungarian Danube section: Arrival time, colonisation characteristics, relative importance. In Proceedings of the 37th IAD Conference, Chisinau, Moldova, 29 October-1 November 2008; pp. 76-81.

17. Puky, M. Status and distribution of invasive crayfish species in Hungary: Pacifastacus leniusculus colonises the Western and South-Western region, Orconectes limosus spreads along Danubian tributaries. In Future of Native Crayfish in Europe, Proceedings of the Regional European Crayfish Workshop, Pisek, Czech Republic, 7-10 September 2009; p. 53.

18. Lenhardt, M.; Markovic, G.; Hegedis, A.; Maletin, S.; Cirkovic, M.; Markovic, Z. Non-native and translocated fish species in Serbia and their impact on the native ichthyofauna. Rev. Fish Biol. Fish. 2011, 21, 407-421. [CrossRef]

19. Hubenov, Z.; Trichkova, T.; Kenderov, L.; Kozuharov, D. Distribution of Corbicula fluminea (Mollusca: Corbiculidae) over an eleven-year period of its invasion in Bulgaria. Acta Zool. Bulg. 2013, 65, 315-326.

20. Bănăduc, D.; Rey, S.; Trichkova, T.; Lenhardt, M.; Curtean-Bănăduc, A. The Lower Danube River-Danube Delta-North West Black Sea: A pivotal area of major interest for the past, present and future of its fish fauna-A short review. Sci. Total Environ. 2016, 545-546, 137-151. [CrossRef]

21. Trichkova, T.; Vladimirov, V.; Tomov, R.; Todorov, M. Guide to Invasive Alien Species of European Union Concern; IBER-BAS, ESENIAS: Sofia, Bulgaria, 2017; p. 184. Available online: http:/ / esenias.org/files/ESENIAS_Atlas_WEB.pdf (accessed on 1 September 2021). (In Bulgarian)

22. Trichkova, T.; Kutsarov, Y.; Todorov, M.; Puky, M.; Hubenov, Z. The Chinese mitten crab Eriocheir sinensis H. Milne Edwards, 1853 (Crustacea: Decapoda: Varunidae), a new invasive alien species to the Bulgarian fauna. Acta Zool. Bulg. 2017, 9, 149-154.

23. Paunović, M.; Csányi, B. Guidance Document on Invasive Alien Species (IAS) in the Danube River Basin; version March 2018; ICPDR-International Commission for the Protection of the Danube River: Vienna, Austria, 2018; p. 61.

24. Bănăduc, D.; Joy, M.; Olosutean, H.; Afanasyev, S.; Curtean-Bănăduc, A. Natural and anthropogenic driving forces as key elements in the Lower Danube Basin-South-Eastern Carpathians-North-Western Black Sea coast area lakes: A broken stepping stones for fish in a climatic change scenario? Environ. Sci. Eur. 2020, 32, 1-14. [CrossRef]

25. Ferreira-Rodríguez, N.; Pavel, A.B.; Cogălniceanu, D. Integrating expert opinion and traditional ecological knowledge in invasive alien species management: Corbicula in Eastern Europe as a model. Biol. Invasions 2021, 23, 1087-1099. [CrossRef]

26. Csányi, B.; Weiperth, A.; Zorić, K.; Bammer, V.; Borza, P.; Trichkova, T.; Weigand, A.; Cardoso, A.C.; Očadlik, M.; Bubíková, K.; et al. Invasive alien species. In Joint Danube Survey 4 Scientific Report: A Shared Analysis of the Danube River; Liška, I., Wagner, F., Sengl, M., Deutsch, K., Slobodník, J., Paunović, M., Eds.; ICPDR-International Commission for the Protection of the Danube River: Vienna, Austria, 2021; pp. 93-106.

27. European Parliament; Council of the European Union. Regulation (EU) No 1143/2014 of the European Parliament and of the Council of 22 October 2014 on the Prevention and Management of the Introduction and Spread of Invasive Alien Species. Off. J. Eur. Union 2014, 317, 35-55.

28. European Parliament; Council of the European Union. Regulation (EU) 2016/1141 of 13 July 2016 Adopting a List of Invasive Alien Species of Union Concern Pursuant to Regulation (EU) No 1143/2014 of the European Parliament and of the Council. Off. J. Eur. Union 2016, 189, 4-8.

29. European Parliament; Council of the European Union. Regulation (EU) 2017/1263 of 12 July 2017 Updating the List of Invasive Alien Species of Union Concern Established by Implementing Regulation (EU) 2016/1141 Pursuant to Regulation (EU) No 1143/2014 of the European Parliament and of the Council. Off. J. Eur. Union 2017, 182, 37-39.

30. European Parliament; Council of the European Union. Regulation (EU) 2019/1262 of 25 July 2019 Amending Implementing Regulation (EU) 2016/1141 to Update the List of Invasive Alien Species of Union Concern. Off. J. Eur. Union 2019, 199, 1-4.

31. International Commission for the Protection of the Danube River (ICPDR). The Danube River Basin District Management Plan: Part A-Basin-Wide Overview; Update 2015; ICPDR: Vienna, Austria, 2015; p. 164.

32. International Commission for the Protection of the Danube River (ICPDR). The Danube River Basin District Management Plan: Part A-Basin-Wide Overview; Update 2021—Draft Version 10; ICPDR: Vienna, Austria, 2021; p. 178.

33. European Parliament; Council of the European Union. Directive 2000/60/EC of the European Parliament and of the Council of 23 October 2000 Establishing a Framework for Community Action in the Field of Water Policy. Off. J. Eur. Union 2000, $327,1-73$.

34. Paunović, M. Standard Operational Procedure for IAS Monitoring during JDS4; Version 1.2. December 2018; ICPDR-International Commission for the Protection of the Danube River: Vienna, Austria, 2018; p. 15.

35. Paunović, M. Manual for IAS Monitoring in the DRB; Version 1.2. December 2018; ICPDR-International Commission for the Protection of the Danube River: Vienna, Austria, 2018; p. 9.

36. Trichkova, T.; Todorov, M.; Botev, I.; Kenderov, M.; Hubenov, Z. Study and Assessment of Ecological Status of the Bulgarian Sector of the Danube River in the Frame of the Joint Danube Survey (JDS4) in 2019. Task: Invasive Alien Species; Project Report, Institute of Biodiversity and Ecosystem Research, Bulgarian Academy of Sciences: Sofia, Bulgaria, 2020; p. 31. 
37. Cardoso, A.C.; Tsiamis, K.; Gervasini, E.; Schade, S.; Taucer, F.; Adriaens, T.; Copas, K.; Flevaris, S.; Galiay, P.; Jennings, E.; et al. Citizen science and open data: A model for invasive alien species in Europe. Res. Ideas Outcomes 2017, 3, e14811. [CrossRef]

38. Roy, H.; Groom, Q.; Adriaens, T.; Agnello, G.; Antic, M.; Archambeau, A.-S.; Bacher, S.; Bonn, A.; Brown, P.; Brundu, G.; et al. Increasing Understanding of alien species through citizen science (Alien-CSI). Res. Ideas Outcomes 2018, 4, e31412. [CrossRef]

39. Bonney, R.; Cooper, C.B.; Dickinson, J.; Kelling, S.; Phillips, T.; Rosenberg, K.V.; Shirk, J. Citizen Science: A developing tool for expanding science knowledge and scientific literacy. BioScience 2009, 59, 977-984. [CrossRef]

40. Best Practices in Citizen Science for Environmental Monitoring; European Commission: Brussels, Belgium, 2020; p. 75. Available online: https:/ / ec.europa.eu/environment/legal/reporting/pdf/best_practices_citizen_science_environmental_monitoring.pdf (accessed on 20 September 2021).

41. Roy, H.E.; Pocock, M.J.; Preston, C.D.; Roy, D.B.; Savage, J.; Tweddle, J.; Robinson, L. Understanding Citizen Science and Environmental Monitoring. Final Report on Behalf of UK Environmental Observation Framework; Centre for Ecology \& Hydrology and Natural History Museum: Wallingford, UK, 2012; p. 173.

42. Tweddle, J.C.; Robinson, L.D.; Pocock, M.; Roy, H.E. Guide to Citizen Science: Developing, Implementing and Evaluating Citizen Science to Study Biodiversity and the Environment in the UK; Natural History Museum and NERC Centre for Ecology \& Hydrology for UK Environmental Observation Framework: Wallingford, UK, 2012; p. 29.

43. Pocock, M.J.; Chapman, D.S.; Sheppard, L.J.; Roy, H.E. A Strategic Framework to Support the Implementation of Citizen Science for Environmental Monitoring. Final Report to SEPA; Centre for Ecology \& Hydrology: Wallingford, UK, 2014; p. 65.

44. Pocock, M.J.; Chapman, D.S.; Sheppard, L.J.; Roy, H.E. Choosing and Using Citizen Science: A Guide to When and How to Use Citizen Science to Monitor Biodiversity and the Environment; Centre for Ecology \& Hydrology: Wallingford, UK, 2014 ; p. 25.

45. Citizen Science Projects on Invasive Alien Species (IAS). Database Repository. EASIN_European Alien Species Information Network, European Commission-Joint Research Centre. Available online: https:/ / easin.jrc.ec.europa.eu/easin/CitizenScience/ Projects (accessed on 13 September 2021).

46. Adriaens, T.; Sutton-Croft, M.; Owen, K.; Brosens, D.; van Valkenburg, J.; Kilbey, D.; Groom, Q.; Ehmig, C.; Thürkow, F.; Van Hende, P.; et al. Trying to engage the crowd in recording invasive alien species in europe: Experiences from two smartphone applications in Northwest Europe. Manag. Biol. Invasions 2015, 6, 215-225. [CrossRef]

47. Johnson, B.A.; Mader, A.D.; Dasgupta, R.; Kumar, P. Citizen science and invasive alien species: An analysis of citizen science initiatives using information and communications technology (ICT) to collect invasive alien species observations. Glob. Ecol. Conserv. 2020, 21, e00812. [CrossRef]

48. Tsiamis, K.; Gervasini, E.; D’Amico, F.; Deriu, I.; Roglia, E.; Shade, S.; Craglia, M.; Cardoso, A.C. Citizen Science Application, Invasive Alien Species in Europe; Publications Office of the European Union: Luxembourg, 2017; p. 88. [CrossRef]

49. Katsanevakis, S.; Deriu, I.; D'Amico, F.; Nunes, A.L.; Pelaez-Sanchez, S.; Crocetta, F.; Arianoutsou, M.; Bazos, I.; Christopoulou, A.; Curto, G.; et al. European Alien Species Information Network (EASIN): Supporting European policies and scientific research. Manag. Biol. Invasions 2015, 6, 147-157. [CrossRef]

50. Schade, S.; Kotsev, A.; Cardoso, A.C.; Tsiamis, K.; Gervasini, E.; Spinelli, F.; Mitton, I.; Sgnaolin, R. Aliens in Europe. An open approach to involve more people in invasive species detection. Comput. Environ. Urban Syst. 2019, 78, 101384. [CrossRef]

51. COST Action CA17122 Increasing Understanding of Alien Species through Citizen Science (Alien CSI) (2018-2022), Horizon 2020 Framework Programme of the European Union. Available online: https:/ /alien-csi.eu/ (accessed on 13 October 2021).

52. Massive Open Online Course (MOOC). 'Have You Seen an Alien?', The European Alien Species Information Network (EASIN), European Commission, Joint Research Centre (JRC). Available online: https:/ / academy.europa.eu/courses/have-you-seen-analien (accessed on 13 October 2021).

53. Hubenov, Z. Recent fauna of Bulgaria-Animalia: Invertebrata. Acta Zool. Bulg. 2008, 60, 3-21.

54. WoRMS Editorial Board. World Register of Marine Species. Available online: http://www.marinespecies.org (accessed on 14 October 2021).

55. Kottelat, M.; Freyhof, J. Handbook of European Freshwater Fishes; Kottelat, Cornol, Switzerland and Freyhof: Berlin, Germany, 2007; p. 646.

56. Nelson, J.S.; Grande, T.C.; Wilson, M.V.H. Fishes of the World, 5th ed.; John Wiley \& Sons, Inc.: Hoboken, NJ, USA, $2016 ;$ p. 707.

57. East and South European Network for Invasive Alien Species-A Tool to Support the Management of Alien Species in Bulgaria (ESENIAS-TOOLS) (2015-2017), Contract No. D-33-51/30.06.2015, Financial Mechanism of European Economic Area 2009-2014, Programme. BG03 Biodiversity and Ecosystem Services. Available online: http:/ / esenias.org/index.php?option=com_content\& view=article\&id=367:esenias-tools-news-1\&catid=88:esenias-tools-project-category\&Itemid=127 (accessed on 26 June 2021).

58. Improving the Bulgarian Biodiversity Information System (IBBIS). Task: 'Development of a Module for Data Collection and Risk Assessment of Invasive Alien Species in Bulgaria', Contract No. D-33-72/20.07.2015, Financial Mechanism of European Economic Area 2009-2014, Programme. BG03 Biodiversity and Ecosystem Services. Available online: https://eeagrants.org/archive/2009-201 4/projects/BG03-0001 (accessed on 26 June 2021).

59. Karaman, I.; Machino, Y. Occurrence of the spiny-cheek crayfish (Orconectes limosus) and the Chinese mitten crab (Eriocheir sinensis) in Serbia. Crayfish News 2004, 26, 19-20. 
60. Rat, M.; Simonović, P.; Glavendekić, M.; Paunović, M.; Stojanović, V.; Karaman, M.; Radišić, D.; Anačkov, G. Overview of the invasive alien species in Serbia. In First ESENIAS Report: State of the Art of Invasive Alien Species in South-Eastern Europe; East and South European Network for Invasive Alien Species; Rat, M., Trichkova, T., Scalera, R., Tomov, R., Uludag, A., Eds.; University of Novi Sad Faculty of Sciences: Novi Sad, Serbia; Institute of Biodiversity and Ecosystem Research, Bulgarian Academy of Sciences: Sofia, Bulgaria, 2016; pp. 91-114. Available online: http:/ / esenias.org/files/08_Esenias_report_2016_95-118_Serbia.pdf (accessed on 20 August 2021).

61. Anastasiu, P.; Preda, C.; Bănăduc, D.; Cogălniceanu, D. Alien Species of EU Concern in Romania, Transylv. Rev. Syst. Ecol. Res. 2017, 19, 93-106.

62. Pârvulescu, L.; Togor, A.; Lele, S.F.; Scheu, S.; Șinca, D.; Panteleit, J. First established population of marbled crayfish Procambarus fallax (Hagen, 1870) f. virginalis (Decapoda, Cambaridae) in Romania. BioInvasions Rec. 2017, 6, 357-362. [CrossRef]

63. Vladimirov, V.; Petrova, A.; Barzov, Z.; Gudžinskas, Z. The alien species of Heracleum (Apiaceae) in the Bulgarian flora revisited. Phytol. Balc. 2019, 25, 395-405.

64. Samoilă, C.; Ruben, I.; Cogălniceanu, D.; Telea, E.A.; Topliceanu, S.; Fănaru, G.; Cobzaru, I.; Drăgan, O.; Iftime, A.; Stănescu, F.; et al. Raport Privind Căile de Introducere a Speciilor de Vertebrate Terestre Alogene în România și a Punctelor Fierbinți ce Necesită Studiu Detaliat; Ministerul Mediului, Apelor şi Pădurilor \& Universitatea din Bucureşti: Bucureşti, Romania, 2020; p. 46. Available online: http:/ /invazive.ccmesi.ro/wp-content/uploads/2020/12/Livrabil-1.2.4-Cai_introducere_vertebrate_terestre.pdf (accessed on 21 August 2021). (In Romanian)

65. Stănescu, F.; Rozylowicz, L.; Tudor, M.; Cogălniceanu, D. Alien vertebrates in Romania-A review. Acta Zool. Bulg. 2020, 72, 583-595.

66. Anastasiu, P. Listă Preliminară Națională a Speciilor de Plante Alogene Invazive și Potențial Invasive din România în Format Tabular; Ministerul Mediului, Apelor şi Pădurilor \& Universitatea din Bucureşti: Bucureşti, Romania, 2020; p. 53. Available online: https:/ /invazive.ccmesi.ro/wp-content/uploads/2020/02/POIM_120008_Subactv.-1.1.2._Lista-plante-invazive.pdf (accessed on 21 August 2021). (In Romanian)

67. Hubenov, Z.; Trichkova, T.; Todorov, M.; Kutsarov, Y. Eriocheir sinensis H. Milne Edwards, 1853. In Guide to Invasive Alien Species of European Union Concern; Trichkova, T., Vladimirov, V., Tomov, R., Todorov, M., Eds.; IBER-BAS, ESENIAS: Sofia, Bulgaria, 2017; pp. 70-73. (In Bulgarian)

68. Koshev, Y.; Nedyalkov, N. Procyon lotor Linnaeus, 1758. In Guide to Invasive Alien Species of European Union Concern; Trichkova, T., Vladimirov, V., Tomov, R., Todorov, M., Eds.; IBER-BAS, ESENIAS: Sofia, Bulgaria, 2017; pp. 146-149. (In Bulgarian)

69. Nedyalkov, N.; Koshev, Y. Myocastor coypus Molina, 1782. In Guide to Invasive Alien Species of European Union Concern; Trichkova, T., Vladimirov, V., Tomov, R., Todorov, M., Eds.; IBER-BAS, ESENIAS: Sofia, Bulgaria, 2017; pp. 138-141. (In Bulgarian)

70. Paunović, M. (University of Belgrade, Belgrade, Serbia). Personal communication, 2021.

71. Petrova, A.; Vladimirov, V.; Georgiev, V. Invasive Alien Species of Vascular Plants in Bulgaria; Institute of Biodiversity of Ecosystem Research, Bulgarian Academy of Sciences: Sofia, Bulgaria, 2013; p. 320.

72. Georgiev, V.; Tsoneva, S.; Kenderov, L.; Trichkova, T.; Todorov, M.; Vladimirov, V. Distribution of Elodea nuttallii, an invasive alien species of EU concern, in Bulgaria. Phytol. Balc. 2019, 25, 417-423.

73. Vladimirov, V. First record of Humulus japonicus (Cannabaceae) in the Bulgarian flora. p. 97. In Proceedings of the Joint ESENIAS and DIAS Scientific Conference and 9th ESENIAS Workshop 'Species, Ecosystems and Areas of Conservation Concern Under Threat from the Invasive Alien Species', Ohrid, North Macedonia, 3-6 September 2019; Trajanovski, S., Trichkova, T., Tomov, R., Vladimirov, V., Kalcheva, H., Zdraveski, K., Eds.; 160p.

74. Vladimirov, V.; Georgiev, V. National reporting of Bulgaria about the invasive alien plants of EU concern in relation to Regulation (EU) 1143/2014. Phytol. Balc. 2019, 25, 407-415.

75. Karapetkova, M.; Zivkov, M. Fishes in Bulgaria, 2nd ed.; GeaLibris Publishing: Sofia, Bulgaria, 2006; p. 215. (In Bulgarian)

76. Koshev, Y.; Nedyalkov, N.; Raykov, I. Creeping up on me: Range expansion of three invasive alien mammals in Bulgaria. Russ. J. Theriol. (Under Review).

77. Janković, D.; Karapetkova, M. Present status of the studies on range of distribution of Asian fish species Pseudorasbora parva (Schlegel, 1842) in Yugoslavia and Bulgaria. Ichthyol 1992, 24, 1-9.

78. Curtean-Bănăduc, A.; Bănăduc, D. Trophic elements regarding the non-indigenous Pseudorasbora parva (Schlegel, 1842) fish species spreading success-Olt River basin, a case study. Rom. J. Biol.-Zool. 2008, 6, 185-196.

79. Stefanov, T.; Trichkova, T. Pseudorasbora parva (Temminck \& Schlegel, 1846). In Guide to Invasive Alien Species of European Union Concern; Trichkova, T., Vladimirov, V., Tomov, R., Todorov, M., Eds.; IBER-BAS, ESENIAS: Sofia, Bulgaria, 2017 ; pp. 102-105. (In Bulgarian)

80. Pavlović, S.; Milošević, S.; Borković, S.; Simić, V.; Paunović, M.; Žikić, R.; Sačić, Z. A report of Orconectes (Faxonius) limosus (Rafinesque, 1817) [Crustacea: Decapoda: Astacidea: Cambaridae: Orconectes: Subgenus Faxonius] in the Serbian part of the river Danube. Biotechnol. Biotechnol. Equip. 2006, 20, 53-56. [CrossRef]

81. Pârvulescu, L.; Paloş, C.; Molnar, P. First record of the spiny-cheek crayfish Orconectes limosus (Rafinesque, 1817) (Crustacea: Decapoda: Cambaridae) in Romania. North-West. J. Zool. 2009, 5, 424-428.

82. Todorov, M.; Trichkova, T.; Hubenov, Z.; Jurajda, P. Faxonius limosus (Rafinesque, 1817) (Decapoda: Cambaridae), a new invasive alien species of European Union concern in Bulgaria. Acta Zool. Bulg. 2020, 72, 113-121.

83. Gergely, J.; Tucakov, M. Amur sleeper (Perccottus glenii): The first finding in Vojvodina (Serbia). Halászat 2004, 97, 158-160. 
84. Nalbant, T.; Battes, K.; Pricope, F.; Ureche, D. First record of the amur sleeper Perccottus glenii (Pisces: Perciformes: Odontobutidae) in Romania. Trav. Mus. Natl. Hist. Nat. Grigore Antipa 2004, 47, 279-284.

85. Šipoš, Š.; Miljanović, B.; Pelčić, L.J. The first record of Amur sleeper (Perccottus glenii Dybowsky, 1877, fam. Odontobutidae) in the Danube River. Int. Assoc. Danub. Res. 2004, 35, 509-510.

86. Popa, L.O.; Popa, O.-P.; Pisică, E.J.; Iftime, A.; Matacă, S.; Diaconu, F.; Murariu, D. The first record of Perccottus glenii Dybowski, 1877 (Pisces: Odontobutidae) and Ameiurus melas Rafinesque, 1820 (Pisces: Ictaluridae) from the Romanian sector of the Danube. Trav. Mus. Natl. Hist. Nat. Grigore Antipa 2006, 49, 323-329.

87. Trichkova, T.; Stefanov, T. Perccottus glenii Dybowski, 1877. In Guide to Invasive Alien Species of European Union Concern; Trichkova, T., Vladimirov, V., Tomov, R., Todorov, M., Eds.; IBER-BAS, ESENIAS: Sofia, Bulgaria, 2017; pp. 98-101. (In Bulgarian)

88. Iacob, M.; Petrescu-Mag, I.V. Inventarul Speciilor Non-Native de Peşti din Apele dulci ale României; Bioflux: Cluj-Napoca, Romania, 2008; pp. 1-89. (In Romanian)

89. Popa, O.-P.; Popa, L.O. Sinanodonta woodiana (Lea, 1834), Corbicula fluminea (O. F. Müller, 1774), Dreissena bugensis (Andrusov, 1897) (Mollusca: Bivalvia): Alien invasive species in Romanian fauna. Trav. Mus. Natl. Hist. Nat. Grigore Antipa 2006, 49, 7-12.

90. Paunović, M.; Csányi, B.; Simic, V. Distribution of Anodonta (Sinanodonta) woodiana (Rea, 1834) in inland waters of Serbia. Aquat. Invasions 2006, 1, 154-160. [CrossRef]

91. Paunović, M.; Csányi, B.; Knežević, S.; Simić, V.; Nenadić, D.; Jakovčev-Todorović, D.; Stojanović, B.; Cakić, P. Distribution of Asian clams Corbicula fluminea (Müller, 1774) and C. fluminalis (Müller, 1774) in Serbia. Aquat. Invasions 2007, 2, 99-106. [CrossRef]

92. Hubenov, Z.; Trichkova, T.; Kenderov, L.; Kozuharov, D. Recent distribution of invasive alien mussels Anodonta woodiana and Corbicula fluminea (Mollusca: Bivalvia: Unionidae \& Corbiculidae) in Bulgaria. J. Int. Sci. Publ. Ecol. Saf. 2012, 6, $269-284$.

93. Skolka, M.; Gomoiu, M.-T. Alien invertebrates species in Romanian waters. Ovid. Univ. Ann. Nat. Sci. Biol.-Ecol. 2001, 5, 51-55.

94. Bij de Vaate, A.; Hulea, O. Range extension of the Asiatic clam Corbicula fluminea (Müller 1774) in the River Danube: First record from Romania. Lauterbornia 2000, 38, 23-26.

95. Hubenov, Z. Corbiculidae-A new family for the Bulgarian recent malacofauna (Mollusca, Bivalvia). Acta Zool. Bulg. 2001, 53, 61-66.

96. Sárkány-Kiss, A. Anodonta woodiana (Lea, 1834) a new species in Romania (Bivalvia, Unionacea). Trav. Mus. Natl. Hist. Nat. Grigore Antipa 1986, 28, 15-17.

97. Hubenov, Z. Anodonta (Sinanodonta) woodiana (Lea, 1834) (Mollusca: Bivalvia: Unionidae)—A new invasive species for the Bulgarian malacofauna. Acta Zool. Bulg. 2006, 58, 35-40.

98. Micu, D.; Telembici, A. First record of Dreissena bugensis (Andrussov, 1897) from the Romanian stretch of River Danube. In Proceedings of the International Symposium of Malacology, Sibiu, Romania, 19-22 August 2004.

99. Popa, O.-P.; Popa, L.O. The most westward European occurrence point for Dreissena bugensis (Andrusov, 1897). Malacol. Bohemoslov. 2006, 5, 3-5. [CrossRef]

100. Rakovic, M.; Popovic, N.; Kalafatic, V.; Martinovic-Vitanovic, V. Spreading of Dreissena rostriformis bugensis (Andrusov, 1897) in the Danube River (Serbia). Acta Zool. Bulg. 2013, 65, 349-357.

101. Todorov, M.; Kenderov, M.; Botev, I.; Hubenov, Z.; Trichkova, T. First records of Pectinatella magnifica (Leidy, 1851) (Bryozoa: Plumatellida: Pectinatellidae) in the Bulgarian shoreline zone of the Danube River. Acta Zool. Bulg. 2020, 72, 507-515.

102. Zorić, K.; Szekeres, J.; Csányi, B.; Kolarević, S.; Marković, V.; Paunović, M. Distribution of the non-native bryozoan Pectinatella magnifica (Leidy, 1851) in the Danube River. Acta Zool. Bulg. 2015, 67, 241-247.

103. Cvijanović, G.; Lenhardt, M.; Hegediš, A. The first record of black bullhead Ameiurus melas (Pisces, Ictaluridae) in Serbian waters. Arch. Biol. Sci. 2005, 57, 21-22. [CrossRef]

104. Pehlivanov, L.; Stefanov, T.; Todorov, M.; Kutsarov, Y.; Trichkova, T. First records of the Black bullhead Ameiurus melas (Rafinesque, 1820) along the Bulgarian section of the Danube River. In Proceedings of the 41st International Association for Danube Research (IAD) Conference-60 years of IAD existence “Tributaries as Key Elements in Sustainable Management of the Danube River Basin", Sibiu, Romania, 13-16 September 2016; p. 34.

105. Groom, Q.J.; Desmet, P.; Vanderhoeven, S.; Adriaens, T. The importance of open data for invasive alien species research, policy and management. Manag. Biol. Invasions 2015, 6, 119-125. [CrossRef]

106. Groom, Q.J.; Adriaens, T.; Desmet, P.; Simpson, A.; De Wever, A.; Bazos, I.; Cardoso, A.C.; Charles, L.; Christopoulou, A.; Gazda, A.; et al. Seven recommendations to make your invasive alien species data more useful. Front. Appl. Math. Stat. $2017,3,13$. [CrossRef]

107. Cardoso, A.C.; Tsiamis, K.; Deriu, I.; D'Amico, F.; Gervasini, E. EU Regulation 1143/2014: Assessment of Invasive Alien Species of Union Concern Distribution; Publications Office of the European Union: Luxembourg, 2021; p. 173. [CrossRef]

108. Trichkova, T.; Vladimirov, V.; Tomov, R. On the Preparation of a National Report on Invasive Alien Species under Art. 24 (1) of the Regulation (EU) No 1143/2014 of the European Parliament and of the Council of 22 October 2014 on the Prevention and Management of the Introduction and Spread of Invasive Alien Species for the Period 2015-2018; Institute of Biodiversity and Ecosystem Research, Bulgarian Academy of Sciences: Sofia, Bulgaria, 2019; p. 22. (In Bulgarian)

109. The Council of the European Communities. Council Directive 92/43/EEC of 21 May 1992 on the conservation of natural habitats and of wild fauna and flora. Off. J. Eur. Union 1992, 206, 7-50. 